\title{
Corrigendum
}

\section{Corrigendum to: The potential of component-resolved diagnosis in laboratory diagnostics of allergy}

Slavica Dodig*, Ivana Čepelak

Department of medical biochemistry and hematology, Faculty of Pharmacy and Biochemistry, University of Zagreb

${ }^{*}$ Corresponding author: slavica.dodig@zg.t-com.hr

This is a correction of Biochemia Medica 2018;28(2):020501. DOI: https://doi.org/10.11613/ BM.2018.020501

Since the publication of this article, the authors have noticed that the Figure 1 was published incorrectly. The correct Figure is presented below. The authors apologize for any inconvenience caused to the readers.

\begin{tabular}{ll}
$\begin{array}{l}\text { labile proteins } \\
\text { low amounts }\end{array}$ & $\begin{array}{l}\text { stabile proteins } \\
\text { large amounts }\end{array}$ \\
\hline CCD $>$ profilins $>$ PR-10-P $>$ nsLTP & Storage proteins
\end{tabular}

FIGURE 1. Increasing of the risk for manifestation of severe symptoms (6). CCD - cross-reactive carbohydrate determinants. nsLTP - nonspecific lipid transport proteins. PR-10-P - pathogen-related-10-proteins. 